\title{
1 \\ To Name and to Remember: The Reunion of 2001
}

'I am very thankful to be here. And there is something more in my heart, something I cannot say.' Sister Teresa González speaks firmly, with characteristic Spanish emphasis in the English she learnt in Australia 53 years ago. She speaks for us all, and we nod. We have sung an ancient liturgy of psalms to remember the eight Benedictine Missionary Sisters who are buried in the cemetery at New Norcia, in Western Australia, and 12 others who are in Spain, France and South Australia. It is the first time, so far as anyone knows, that the names of these women have been read together here, or anywhere.

The ceremony has been simple. In the open air, with the wind in the gum trees beyond the wall and the galahs striking out occasionally over the chant, we mark the graves of eight women who came from Spain to work with Aboriginal children in Australia's only monastic town. The evening light is clear, the sun is still warming the gravel and the wildflowers are fresh on the weathered graves. It is powerful to name and to remember.

Our vacant chairs still form a circle around the graves, and in the ring alongside the simple crosses of the Benedictine sisters there is another mound, unmarked. Sister Teresa and I stare at the baked ground: 'Is this Gracie?' I ask. I am guessing. I know a story from newspaper fragments. Like many of the women who grew up at St Joseph's Native School and Orphanage, Miss Grace Williams was born in the town and spent her life here. She did not know her father 'from America', and until she was 
four she had lived with her mother's people in a mission cottage. ${ }^{1}$ Then, in 1899 or 1900 she was committed to the care of the monastery. She was one of the children living there when the first sisters arrived in 1904 to take over the running of St Joseph's from the monks. She was there as new buildings were built and as the Benedictine Missionary Sisters were made an official community of New Norcia. Grace never left. Whether poor health and bad eyesight determined things or whether Pax, the parish's newspaper, was right to report she had 'found her happiness in the secluded life of that Institution and in co-operating with the Benedictine sisters in their work for the native children' we do not know. ${ }^{2}$ But when she died in 1956, aged 61, it was two years since she had taken the name 'Gertrude' and pledged herself to the Rule of Benedict as an oblate in private vows. Her funeral was a solemn occasion for the Benedictine monks and the sisters, as well as for family from New Norcia and Perth. She was buried in a Benedictine habit alongside the missionary women. But her grave was not marked. 'I think this is Grace Williams's grave', I tell Teresa. 'Grace? Ah yes! Gracie. She was very close to the sisters. The procession, the funeral, I think I was here.' Our liturgy did not name Grace or Gertrude Williams. Her grave might be part of the circle. But who am I to remember? How can I presume to know the story in her names?

Grace's grave disrupts the circle and makes space between sharp categories. I wonder what she thought of her insider-outsider status? So much of this story is like that, including my own part in it. I have known ever since I recorded long interviews with each of the sisters in 1999 that telling their story could not be an austere academic exercise. 'Don't praise anybody!' Teresa had warned. 'You will write what you like, of course, but don't praise anybody.' I quote her feisty injunction back to myself again and again, hearing the sisters' collective impatience with sentiment and the wariness that shadows conversations about their motivations and convictions. The deepest realities, 'these are what God knows', says Sister Visitación. Talking too much can trivialise decisions that lie beyond words. Discussion might belittle what it meant to live so far from home and family, to work so hard, and to believe or hope so fiercely that this was as God wished. They did not understand it. They learnt to distrust smooth, plausible words. There is pain now, with confusion and regret about what the institution meant in Aboriginal lives. 'We have much to pray for, and not much to be proud of', Visitación insists quietly. Naming needs time.

1 Pax, 22 July 1956, 3. See also Lois Tilbrook, Nyungar Tradition: Glimpses of Aborigines of SouthWestern Australia 1829-1914 (Nedlands, WA: University of Western Australia Press, 1983), 230. 
'Don't praise anybody!' It is a strange warning, but welcome. A promotional story will not do. These women have become my friends, and they are the link that binds my friendship with the Aboriginal women and men of New Norcia. They have also been missionaries, caught in the government policies that removed Aboriginal children from their families, committed to religious welfare before, and sometimes against, social justice and political rights. 'Don't praise anybody'. Teresa chooses her emphasis. Of course not, Sister. It is much easier to stereotype the mission enterprise as misguided, mistaken and cruel: to focus on abuse covered by institutional pride, to frame it all as more wilful oppression linked to destructive, arrogant religion. Much easier, but not good enough, not full enough, not fair. It would break hearts again but not heal them. And the Aboriginal women who have asked these sisters 'home' again and have gathered with them in the cemetery are hoping for healing, not heartbreak. Emotion runs deep. Even for us at the edge, tears are the most likely language. Women who have fought all their lives against the threat that their own children might end up in care are bringing their grandchildren to town, proud and keen that the next generation might meet 'the ladies who looked after Nanna'. It makes a difference how we name, how we remember.

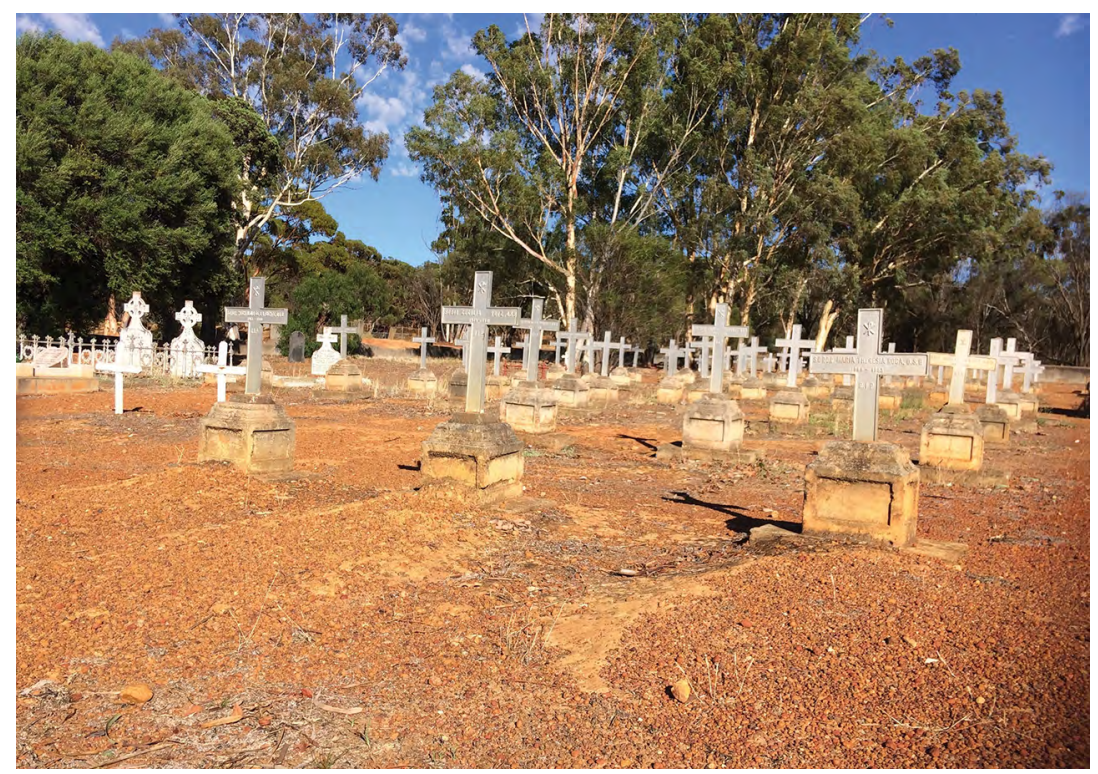

Figure 1.1: New Norcia cemetery, graves of the Spanish Benedictine Missionary Sisters, March 2017.

Source: Author's collection. 
A BRIDGE BETWEEN

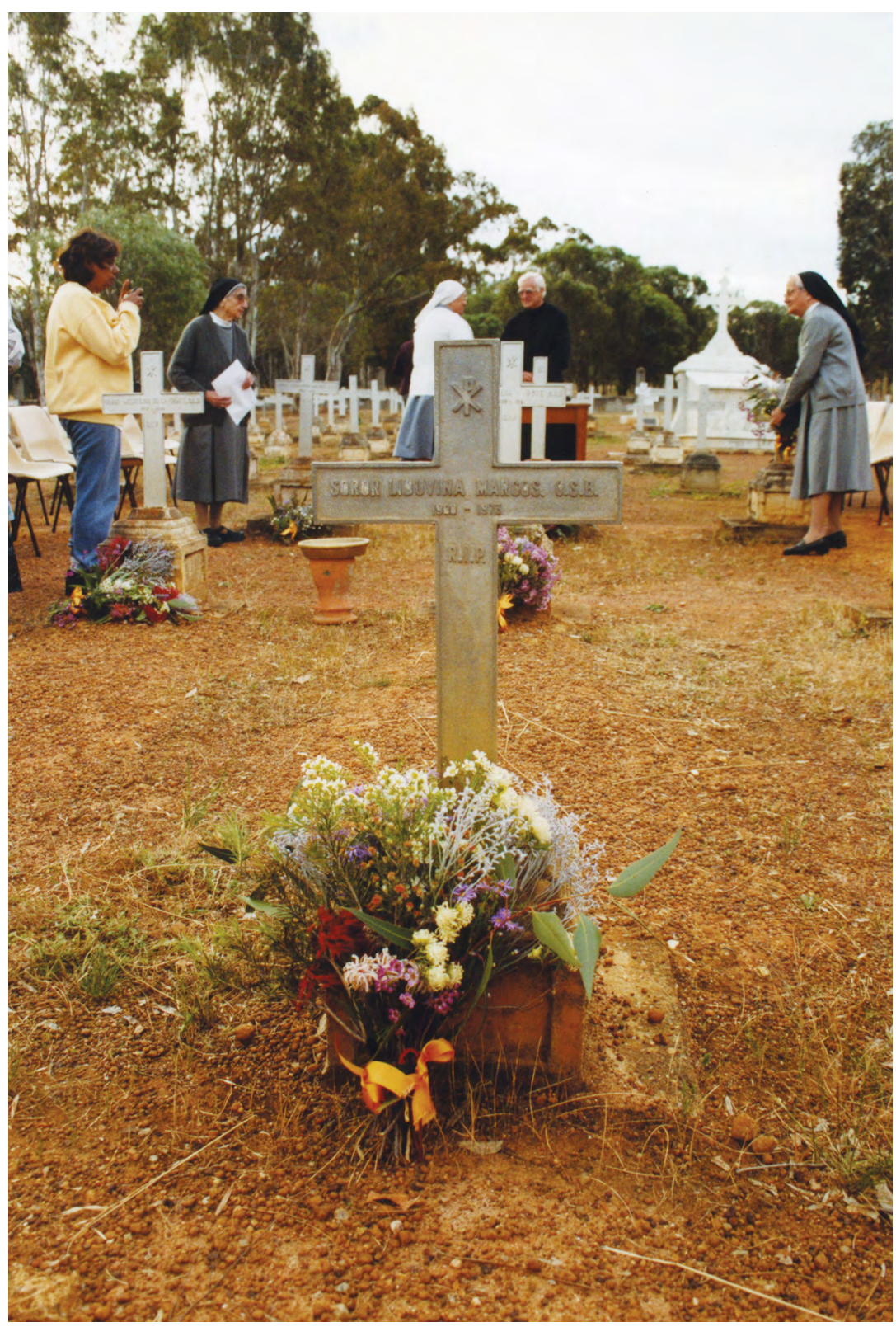

Figure 1.2: Ms Mae Taylor, Sr Francisca Pardo, Sr Visitación Cidad, Fr Anscar McPhee and Sr Teresa González in the cemetery at New Norcia after the memorial service in October 2001.

Source: New Norcia Archives (NNA) W6-B4-4-213. 
We are a small crowd in the cemetery. There will be hundreds in town tomorrow for bigger celebrations, at the Mass, the barbecue and the opening of a new museum display. This occasion, in the late afternoon on Friday 19 October 2001, is a New Norcia gathering: the community of Benedictine monks, some employees from the town, Aboriginal women and men who grew up in New Norcia, and just a few others who know the honoured guests. These guests, the visiting Benedictine sisters, have come back to New Norcia at the invitation of some of the women who grew up at St Joseph's. For two years and more, Mae Taylor has been building support for this extraordinary gathering. Back in New Norcia herself after her 1950s childhood spent at St Joseph's and working in the monastery kitchen, Mae shaped a daring plan. Moved by the visit of first one and then another individual sister to the mission town, she enlisted the support of the abbot's secretary and the blessing of the abbot to write to a string of church administrators seeking permission for five elderly Spanish women to travel to a reunion. It was a bold proposal but, with other local Aboriginal women, Mae persisted. Now Sisters Teresa González Francisca Pardo, Pilar Catalan, Visitación Cidad and Carmen Ruiz are here. They have flown halfway around the globe on airfares paid by their former students. In these extraordinary days, the former missionaries and the 'St Joseph's girls' retrace their experiences and celebrate, mourn, and pray. They remember, together. In the context of the people and the place that has itself shaped understanding, relationships are being tested, claimed, and renegotiated. Mae is in the crowd now, chuckling at one of the elderly sisters, 'one of my mothers', who takes a ritual bouquet apart to have flowers for another grave that she says needs attention. 'Always had her own idea', Mae says, grinning at the small rebellion, naming it, as a daughter might, and remembering.

There have been flowers for the sisters since they arrived in town more than a week ago. Mae, and her sister Sheila Humphries, had made sure of that. 'Welcome home', the card said. Were they home? Actually, Teresa, Francisca and Pilar live in Madrid; Visitación (Visi) has come from Kalumburu in the far north Kimberley; Carmen from Jamberoo in New South Wales. But New Norcia is as surely 'home' as any place could be for these Spanish sisters. Now in their seventies and eighties, they first lived here as young women. That experience has defined them as strongly as any in their lives. In Carabanchel, among many convents in that outer suburb of Madrid, they are the 'Australian Sisters'. Visi has brought greetings from Schollie, Sister Scholastica, who will not now leave the Kimberley. 
Sister Anne, the Australian-Irish recruit who was once Sister Pius, has come from Perth, and Sister Veronica, once Marie, the oldest of the local Willaway girls, who joined the Benedictines as a teenager, has come from her convent in Nebraska in the United States to be with the Spaniards too. Like the Spanish, she has been part of the Benedictine Missionary Sisters of Tutzing since 1986, when the New Norcia community merged with that German-founded group, now strongest numerically in the Philippines and Korea. The New Norcia sisters are together again for the first time since their former congregation shifted its motherhouse from New Norcia to Spain in 1974.

Yesterday, sitting in the convent kitchen waiting for the kettle to boil there was a silence, broken as Sister Carmen mused: 'You know, we did not bring a pack of cards'. She met Sister Visi's sudden astonishment: 'My goodness, we have not seen each other for almost 40 years, and we are talking about cards! Can we find nothing to say?' The kettle boils, and the brisk Spanish exchange merges into afternoon tea, but the question lingers at the heart of the reunion. Re-create an old life where playing cards and checkers marked brief snatched holidays? Or talk of the realities since then, the changes, discoveries, losses, betrayals, pain, and enduring hopes? Or take the risk that there is nothing to say? 'Did we do nothing good?' Teresa has asked. Risk all the words that can never explain? If we name it, we must also remember.

Veronica Willaway and her sister, Rose Narkle, have sat together by the gravesites. They are Aboriginal Australians of the Yued people and their forebears were linked to the mission from its earliest decades after the two Spanish monks, Rosendo Salvado and Joseph Serra, made their way to the district in 1847. Their grandmother's grandmother, Eliza Tainan Willaway, spoke on behalf of the women and girls of the mission in the 1880s, in keeping with Salvado's nineteenth-century policy that Aboriginal women, not European nuns, would be his deputies as St Joseph's took shape. $^{3}$ Their parents, grandparents and forebears back to the time of the first missionaries in the 1840 s are buried in this cemetery too. Veronica ran away from home, from one of the mission cottages, to join the sisters at the age of 14. 'Mum chased her with a broom one day', observes Rose unromantically, 'and she went to the sisters instead and stayed.' It was

3 For example, her speech of welcome to Cardinal Moran, West Australian Catholic Record (hereafter Record), 10 February 1887, 4; Katharine Massam and John H. Smith, 'New Norcia and Federation: A Story of Nation, Church and Race', New Norcia Studies 9 (2001): 13-14. 
all of 500 metres across level ground from the cottage to the convent, 500 metres and a journey between worlds. Another local girl, Vera Farrell, was already there, professed as Sister Cecilia. Rose herself might have joined too, and there were four other former students of St Joseph's who did become postulants. Veronica stayed, from New Norcia to Barcelona, to a stint in the Kimberley, and now the United States. Later, much later, in an interview in Nebraska, Veronica disputes the implications of my draft and a summary of the Benedictine women. Her challenge means a lot. Getting this right matters to us both. ' 'Well, let's put it this way', she proposes: 'They weren't feminine, nor were they motherly. They were not manly. They were just their own selves. They were there to be religious. And you know back then, that feminine would have been a bad thing.' Interpretations diverge, demand precision and defy it, memories tangle, nuance matters. How do we name that?

That St Joseph's was a tough institution is beyond doubt. Efficiency and economy prevailed in a context that was sometimes barbaric. Generally anxious for government support and approbation, New Norcia did not challenge decisions unless they impacted on religious commitment. 'I am not prepared to sanction the fillings', noted the cost-conscious official on a request for a dentist to visit St Joseph's in March 1926, for example. There were prominent Catholic dentists in Perth, but no one at New Norcia sought their help or suggested the mission could contribute to the cost. ${ }^{6}$ As a result, instead of the plan for 26 extractions and 44 fillings among the 25 girls at St Joseph's, including only one patient who would have more than two teeth pulled, there were only extractions: 66 in total. Grace Williams lost four teeth that day; one of her friends lost seven, and three others lost five. ${ }^{7}$

4 On dynamics in oral history interviewing, Laura Rademaker, "We Want a Good Mission Not Rubbish Please”: Aboriginal Petitions and Mission Nostalgia', Aboriginal History 40 (2016): 119-23, 138; Gillian Cowlishaw, 'On "Getting It Wrong”: Collateral Damage in the History Wars', Australian Historical Studies 37 (2006): 181-202.

5 Veronica Willaway, Interview, Nebraska, 8 July 2012.

6 R. F. Stockwell, 'Henderson, Gilbert Dowling (1890-1977)', Australian Dictionary of Biography, National Centre of Biography, The Australian National University, adb.anu.edu.au/biography/hendersongilbert-dowling-12975/text23449; published first in hardcopy 2005, accessed 5 November 2016.

7 E. E. Copping, Deputy Chief Protector of Aborigines, 'New Norcia Mission - Subsidy and General', State Records Office of Western Australia (SROWA) S2030 cons993 1926/0350, 12 February, 16 February and 15 March 1926. 
There were also tyrannies and abuse initiated at St Joseph's itself. The stories have begun to surface and more will follow. At the time of the reunion, there are records of despair in archives and elsewhere. One trail from as late as May 1968 concerns a 15-year-old state ward whose hair was cut off, 'in a very short male style, ${ }^{8}$ as punishment for running away to her home at Goomalling Reserve. The younger sisters were appalled at the archaic practice and the superintendent was somehow alerted, but the girl told him, 'Anyone can do anything to us and nobody cares'. 'Her name is on the record, but this is not a public memory. Will she be at the reunion? Is her family coming? No one is sure.

For Rose Narkle and Veronica Willaway this reunion is a family gathering. When they arrived yesterday with nephews, nieces and grandnephews, I hoped I might see Paul, Rose's eldest son. But he will be in town tomorrow, Rose says, coming up for the day, with his uncle, the cousins, dozens of others. This is about family, remembered and not, named and unnamed.

At the beginning, Paul Willaway's friendship had connected me into this project. From the first days it was clear that the 'St Joseph girls' held keys to the Benedictine sisters' stories, and so I drove to Moora, the next town along the highway from New Norcia, to talk to Mary and Gloria and Fatima, three of the Drayton sisters. As we turned on the tape recorder, the first question was for me: 'So, how do you know Paul?' I explained we'd been students together at different Perth universities, he in Social Work at Curtin, me in Arts at the University of Western Australia. We'd both joined the Tertiary Young Christian Students, a group that shaped my ideas about social justice and Catholic commitment. At meetings when that group set about social analysis, Paul's single presence always brought the proportion of Aboriginal people among us way out ahead of the national statistical average. He was then my one Aboriginal friend. I dropped his name into the tape recorder at that first interview, claiming the history and grateful for the link. It was my first lesson in the relationships that sustain the memory of the Sisters and guard the telling of their story. There is power in the naming; we all know that.

8 J. S. Beharell, Superintendent, to Commissioner of Native Welfare, 24 May 1968, Department of Child Welfare, 'Missions - Private - New Norcia - General Correspondence', SROWA S1099 cons $2532 \mathrm{~A} 0403 \mathrm{v} 1$.

9 Beharell to Commissioner of Native Welfare, 24 May 1968. View from the younger sisters: Anne Moynihan, Interview, North Perth, 19 March 1999. 
Named simply Life at St Joseph's, the painting by Yued artist Sheila Humphries was the focal point of the main liturgy of the reunion fortnight. It now hangs at the centre of the commemorative museum display. Sheila summed up her work, saying:

The painting tells the story of our life in St Joseph's Orphanage. I was inspired to paint it with the love that I had, and the memories that I had, of the Sisters and the girls in the home. ${ }^{10}$

The first aim of this book is to reflect on what it means to hear those stories of love and memories. I hope to pay attention to the account of these missionary women that can be told only 'by heart'. The jumble of material in their scattered archives is not only emotional, personal and conflicting (as historical evidence often is) but also concerned above all with the things of the spirit, with the immaterial matters of the heart. Emotion has become a focus for historical reflection across many different periods, but religious belief is not strictly an emotion. The particular intersections of faith and passion that flow through this story make sense only theologically, not in rational or even psychological terms. What scholarly and human tools might we forge to help us explore 'soul' as a category of history? How might we set 'love' and 'faith', and also 'pain' and 'anger', alongside stories of race, class and gender that we already know shape the discussion of our past?

Public and also confidential accounts of neglect and great suffering in institutions like St Joseph's, and at New Norcia itself, have begun to fill the silences in the institutional records. Calls since the mid-1990s brought the harm done in and by institutions that failed to protect children from abuse into clearer view. Through the years of this project, the church's Towards Healing process, the state government's Redress scheme and, finally, the 2013-17 Royal Commission into Institutional Responses to Child Sexual Abuse sought to acknowledge and respond to crime and coverup in the past, including five particular claims against two Benedictine sisters at St Joseph's. ${ }^{11}$ More broadly, the allegations of inadequate

10 Sheila Humphries, Interview with Sr Anne Carter, New Norcia, 10 June 2002, New Norcia Studies 10 (2002): 36-37.

11 Royal Commission into Institutional Responses to Child Sexual Abuse, Analysis of Claims of Child Sexual Abuse Made with Respect to Catholic Church Institutions in Australia, Commonwealth of Australia, February 2017, 135, www.childabuseroyalcommission.gov.au/sites/default/files/REPT.0012.001.0001. pdf; accessed 26 March 2018. See also 'Towards Healing', Truth, Justice and Healing Council, www. tjhcouncil.org.au/support/towards-healing.aspx; accessed 26 March 2018; Redress WA (2008-2011), Find \& Connect, 16 January 2012, last modified 12 February 2015, www.findandconnect.gov.au/ guide/wa/WE00505\#tab1; accessed 26 March 2018; Royal Commission into Institutional Responses to Child Sexual Abuse, Final Report, 15 December 2017, www.childabuseroyalcommission.gov.au/finalreport; accessed 26 March 2018. 
education, hunger, violence and fear of particular places associated with sexual predators cast a pall over all accounts of the institution. Members of the reunion shared their experience in the various enquiries, advocated for healing through roles at Yorgum, the Aboriginal Link-Up agency in Perth, with the New Norcia Aboriginal Corporation, in government departments and local reconciliation committees. ${ }^{12}$ The pain and anger of those making the allegations must be heard, alongside their vehement hope that speaking out will raise awareness and ensure healing. Together with sufficient funding to assist survivors of abuse, healing also depends on wider recognition in the community that churches cooperated with government in an entrenched system that dispossessed Aboriginal people of their land and disrupted families over generations.

This is hard for the dedicated Benedictine women to hear. As they come to terms with the accusations there is shock and disbelief, disappointment and shame, stoic determination to listen well, and also gratitude that among the Aboriginal voices calling for justice some extend their hope for understanding and healing to include the Benedictines themselves. The institution was abusive, make no mistake; and yet the Aboriginal women insist on a more complex story. When descendants see a stolen childhood in photos on Facebook ('Those nuns look like Nazis') the women themselves comment warmly: 'Lovely Sister Carmen.' 'Sister Margaret: warrior woman!' 'Sister Teresa was our teacher. Everyone loved her. She taught us to dance.' 'We send our love.' While the narrative about injustice at St Joseph's is rightly aggressive, it is coupled with generous acknowledgment of the Benedictine sisters and of strong bonds with individuals among them.

This book draws on interviews with Aboriginal women who grew up with the Benedictine sisters, but it is not a history of St Joseph's Native School and Orphanage. That work with a focus on the experience of the children in care remains to be done, and I hope by an Aboriginal historian. This book is a history of the group of Benedictine Missionary Sisters whose story taps a rich vein of memory below the surface of the Spanish Benedictine mission of New Norcia. It gathers a fragmented story from the margins of the archive and offers a point of entry into material to support further work. I will not be able tell a complete and comprehensive

12 'New Norcia Healing Camp: The Road to Healing', Yorgum Newsletter, March 2014, n.p. 
story, but it may be that by reflecting on why a smooth account is not possible we can come to understand more of what it means for historians, and all Australians, to hear stories such as those told by and about the Benedictine Missionary Sisters.

\section{Remembering in context}

From 1904 until 1974 the hidden lives of the Benedictine Missionary Sisters of New Norcia stood at the heart of the complex dynamics of the famous mission town. Through the nineteenth century New Norcia's founder, Rosendo Salvado, had steadfastly refused offers from European women, and especially Spanish Benedictine women, to join his monastic foundation among the Yued people of the Victoria Plains. ${ }^{13}$ On Salvado's death in 1901, the decision of his successor to invite a group of nuns to replace Aboriginal matrons at St Joseph's Native School and Orphanage triggered the events that established the missionary sisters as a diocesan congregation within the mission and saw the expansion of their work in succeeding decades to the Kimberley (1931), Bindoon (1948), Spain itself in 1958, and Perth's suburbs in 1973. Their collective biography touches the most pressing questions in Australian historical writing, bringing issues of race, gender and class together in a crucible of religious commitment. Their story offers a close study of the development of a community that was transnational in scope and holds wide significance.

The pages that follow focus on the Benedictine sisters in order to demonstrate the fundamental significance of the emotional and physical work of the institution they ran and the network of relationships that shaped their lives. From the South American and Mexican foundresses, through the chain migration of young women who travelled from villages near Burgos in the north of Spain to join them in the 1920s, 30s, 40s and 50s, to the Anglo-Celtic and Aboriginal Australians who joined in the 1950s the Benedictine Missionary Sisters navigated between boundaries. They were Spanish-speaking Catholic women in Protestant, White Australia, they were 'sisters' not monks in a monastic town, they were missionaries in an institution that began as a whitewashed hut among the other whitewashed huts that housed Aboriginal families,

13 For example, Rosendo Salvado to Venancio Garrido, 20 March 1866, Salvado Correspondence by Teresa De Castro and David Barry OSB, New Norcia Archives (NNA) 2-2234A/21.069. 
they exercised authority over the children of those families on behalf of a coercive government as they sought to modernise and professionalise first the school at New Norcia and then the childcare centre in Perth's northern suburbs to provide alternatives for the people. The reunion of key members with the Aboriginal women who had grown up at St Joseph's in 2001 points to the significance of their memory and of this story for the future of reconciliation in Australia.

The history of Australia's Spanish Benedictine women connects with vibrant scholarly conversations about the history of Catholic women religious ('nuns' and 'sisters') internationally. This field has shifted well away from devotional or hagiographical accounts to embrace the insights of feminist and post-colonial history and theology, alongside new digital technologies. ${ }^{14}$ Sustained by two thriving networks with regular conferences, recent scholarship on women religious is taking account of the transnational significance of their communities, the complexity of religious identities, and the subtleties of convent engagement in political and social concerns. ${ }^{15}$ The contribution of Catholic women religious to education, nursing and pastoral work has been recognised gradually since the rise of women's history in the 1960s and also subjected to more sophisticated questions. ${ }^{16}$ This book about New Norcia's sisters stands alongside the growing literature on 'oblate' congregations and Black American women religious, and adds the unique Spanish-speaking missionary community to the work on predominantly Irish communities

14 Deirdre Raftery, 'The "Third Wave" Is Digital: Researching Histories of Women Religious in the Twenty-First Century', American Catholic Studies 128 (2017): 29-50.

15 See especially the international bibliographies maintained by History of Women Religious of Britain and Ireland, historyofwomenreligious.org/women-religious-bibliography/, and research resources curated by Conference on the History of Women Religious: www.chwr.org/researchresources; accessed January 2019.

16 For example, the special issue on women religious Paedagogica Historica: International Journal of the History of Education 49 (2013); Janice Garaty, Lesley Hughes and Megan Brock, 'Seeking the Voices of Catholic Teaching Sisters: Challenges in the Research Process', History of Education Review 44 (2015): 71-84; Carmen Mangion, 'Developing Alliances: Faith, Philanthropy and Fundraising in Nineteenth-Century England', in The Economics of Providence: Management, Finances and Patrimony of Religious Orders and Congregations in Europe 1773-1931, ed. Maarten van Dijck, Jan de Maeyer, Jimmy Koppen and Jeffrey Tyssens (Leuven: Leuven University Press, 2013); Susan O’Brien, Leaving God for God: The Daughters of Charity of St Vincent de Paul in Britain, 1847-2017 (London: Darton, Longman \& Todd, 2017). 
in Australia. ${ }^{17}$ It also contributes a close study of a Catholic community to historical work on women missionaries in Australia where the emphasis so far has been on Protestant experience, and brings Western Australia into focus within a larger narrative of Catholic history and women's history, often more informed by archives from the eastern seaboard, especially in Sydney and Melbourne. ${ }^{18}$

New Norcia is central to the history of religion in Australia, and both the monastic town and its charismatic founder already have a profile in histories of nineteenth-century missionary enterprise, as well as of empire and culture. ${ }^{19}$ The mission founded in the Kimberley in 1908 by monks from New Norcia has also received attention, especially in studies of Aboriginal experience by Ian Crawford and Christine Choo. ${ }^{20}$ As the source materials about Salvado and his work grow richer for Englishlanguage readers there is a need to examine the mission in the south that

17 Rosa Bruno-Jofré, The Missionary Oblate Sisters: Vision and Mission (Montreal: McGillQueen's University Press, 2005); Diane Batts Morrow, Persons of Color and Religious at the Same Time: The Oblate Sisters of Providence, 1862-1860 (Chapel Hill: University of North Carolina Press, 2002); M. Shawn Copeland, 'Building up a Household of Faith: Dom Cyprian Davis OSB and the Work of History', US Catholic Historian 28, no. 1 (2010): 53-63. On Australian communities, M. Rosa MacGinley, A Dynamic of Hope: Institutes of Women Religious in Australia (Darlinghurst, NSW: Crossing Press, 2002); Stephanie Burley, 'An Overview of the Historiography of Women Religious in Australia', Journal of the Australian Catholic Historical Society 26 (2005): 43-60; and for recent examples of Australian community histories, Mary Ryllis Clark, Loreto in Australia (Sydney: University of New South Wales Press, 2009); Margaret Walsh, The Good Sams: Sisters of the Good Samaritan 1857-1969 (Mulgrave, Vic.: John Garrett Publications, 2001).

18 Patricia Grimshaw, 'Rethinking Approaches to Women in Missions: The Case of Colonial Australia', History Australia 8 (2011): 7-24; Regina Ganter and Patricia Grimshaw, 'Introduction: Reading the Lives of White Mission Women', Journal of Australian Studies 39 (2015): 1-6. On women across the churches, Anne O'Brien, God's Willing Workers: Women and Religion in Australia (Sydney: University of New South Wales Press, 2005).

19 Tom Stannage, 'New Norcia in History', Studies in Western Australian History 29 (2015): 125-30; George Russo, Lord Abbot of the Wilderness: The Life and Times of Bishop Salvado (Melbourne: Polding Press, 1980); Rosendo Salvado, The Salvado Memoirs: Historical Memoirs of Australia and Particularly of the Benedictine Mission of New Norcia and of the Habits and Customs of the Australian Natives, trans. E. J. Storman (1977; Nedlands, WA: University of Western Australia Press, 1998); David Hutchinson ed., A Town Like No Other: The Living Tradition of New Norcia (1995; Fremantle, WA: Fremantle Arts Centre Press, 2007). For current research trends, see the journal New Norcia Studies; and John H. Smith, ed., Rosendo Salvado: Commemorating Two Hundred Years (New Norcia: Benedictine Community of New Norcia, 2014).

20 Ian Crawford, We Won the Victory: Aborigines and Outsiders on the North-West Coast of the Kimberley (Fremantle, WA: Fremantle Arts Centre Press, 2001); Christine Choo, Mission Girls: Aboriginal Women on Catholic Missions in the Kimberley, Western Australia 1900-1950 (Crawley, WA: University of Western Australia Press, 2001). 
continued on the strength of his legacy. ${ }^{21}$ New Norcia's institutions in the twentieth century have received comparatively less attention although they remained central to the lives of Aboriginal Australians. That there were Spanish women involved in the work, and that the community came to include Anglo-Australian and Aboriginal Australian sisters, remains largely unknown. A Bridge Between addresses that silence.

Without pretending a complete history is possible, this book traces the story of the Benedictine sisters who worked in the mission town. By honouring a stream of memory that bubbles just below the surface of the written history of New Norcia, I hope to prompt more conversation and encourage the gathering of further material for reflection. Again and again, this story is about the commitment-to a community and the people involved, to a way of life, to God-that formed a thread of meaning to link realities that threatened to spin apart.

The existing material is scattered and elusive. The archives at New Norcia are rich in glimpses of sisters, 'crunching across starlit gravel ... wrapped in meditation', ${ }^{22}$ but scant on detailed depictions. It is simple to find affirmations 'that no band of Benedictine missionaries ever showed a nobler spirit of sacrifice, ${ }^{23}$ and even straightforward to find their photographs, but it is much harder to name the members of this group or describe what they did. Public memory swings between quaint women gliding to chapel in the dawn light and fierce disciplinarians pulling children into line by the earlobe. The record has been strong on 'finding happiness in the secluded life ${ }^{24}$ but silent on the intense interactions and flashes of creativity that marked the reality of days in the school, the sheer hard work of the laundry, the challenges and accomplishments of the kitchen. Much was never recorded, and a bonfire instigated by the Benedictine women when they left Australia destroyed children's schoolbooks and class work and all the odds and ends that would never be used again.

21 The Abbey Press is publishing primary material with the intention of resourcing fresh scholarly work; for example, Théophile Bérengier, New Norcia: The History of a Benedictine Colony in Western Australia 1846-1878, trans. Peter Gilet (Northcote Vic.: Abbey Press, 2014); Rosendo Salvado, Report of Rosendo Salvado to Propaganda Fide in 1883, trans. Stefano Girola (Northcote, Vic.: Abbey Press, 2015). Salvado's diaries transcribed and translated into English by Teresa De Castro and David Barry are forthcoming. On Salvado's correspondence, see Teresa De Castro, 'Westaustralianae: New Norcia’s Archive', www.geocities.ws/CollegePark/Field/4664/Historyserver/westraliana/index.htm; accessed January 2019.

22 'New Norcia Today', St Ildephonsus College Magazine, 1929, 5-9.

23 'First Sisters at Drysdale River Mission', St Ildephonsus College Magazine, 1931, 34-40.

24 Pax, 19 September 1954, 4. 
At first, it seemed all that remained were the buildings themselves. When I taught history at the University of Western Australia in the 1990s I brought groups to stay at the 'Old Convent', and it was never quite clear who the mysterious Spanish sisters had been, how they had connected to the Benedictine traditions the students had come to see, or why the museum and art gallery occupied their building without telling their story. Preparation for the 2001 reunion itself prompted work to restore some awareness of the women in the mission, with artefacts and accounts of life at St Joseph's gathered into an exhibition in the former convent chapel. It is a first step, a collaboration that might see New Norcia commemorated as a 'site of conscience', one day, in the future. ${ }^{25}$ In the museum storerooms (areas the Benedictine sisters see as former classrooms and dormitories) there are artefacts that survived because they were still needed: statues from the chapel and classrooms, washing machines, sewing machines, cooking pots and kitchen utensils, sporting trophies, stray toys and oddments of clothing. They build a picture.

The photographs are even more evocative. They are held in the archive at New Norcia and with the communities in Spain and the Kimberley, both promotional and documentary shots taken for publication over the years, and family snaps. Some appear in these pages but several of the most dynamic remain unpublished as families reserve the right to their own privacy or respect the rights of others. As the footnotes indicate, some of those have been entrusted to the Storylines project at the State Library of Western Australia who will manage protocols about access. A treasure in one context is a trigger in another. Not many of the images are catalogued, but they illustrate and deepen the conversations. As stories flow in some 30 interviews in Spanish and English, identities emerge from the uniform rows, and individual faces match with names and dates. In Kalumburu, while the air-conditioner hums, Schollie and Visi take me through their albums, with images of mentors and earlier generations mixed in with their own 40-plus years in the north. There will be several visits to Spain, to the community in Madrid, their ongoing outreach in Barcelona, and Valladolid where the library holds the relevant newspapers. I stay with the Sisters, in the residence they founded for students, in various convent guesthouses as the search for material fans out, sharing their life

25 For example, Bonny Djuric, Lily Hibberd and Linda Steele, 'Transforming the Parramatta Female Factory Institutional Precinct into a Site of Conscience', The Conversation, 4 January 2018, theconversation.com/transforming-the-parramatta-female-factory-institutional-precinct-into-a-siteof-conscience-88875; accessed 2 April 2018. 
and included in their network of hospitality. Each visit includes Burgos, Napoleon's capital and then Franco's, surrounded by the farming villages that were home to most of New Norcia's missionaries and the network of Benedictine connections that brought them to Australia. On the first visit, I photocopy images; later, when technology catches up with the needs of this project, we take precious selections to be scanned. There is only one copy of a photo of Sister Teresa at the piano with her first student, and her reminder is earnest: 'Do not hurt my photo!' The material matters: it names relationships.

The written sources are scattered in Spain and in Belgium as well as in various archives in Australia. Some material in government files and at New Norcia is rightly restricted to family members of the children whose names it also records, some material in Spain was lost as religious houses were burnt in the Spanish Civil War, other fires claimed material written by the sisters because 'anyone might read them'. ${ }^{26}$ The Notebooks of Sister Felicitas from the 1920s were the closest thing the community had to a diary but Teresa burnt them in the 1980s. Their fate comes to light in a typical group interview upstairs in the airy Madrid convent: Teresa, Francisca and Pilar respond to my questions in Spanish; Sister Maria Gratia from the Philippines takes notes to help keep track of the recording later. She is their community leader and has known these Spanish sisters since they merged with her Tutzing community in the 1980s but she has not heard the mission stories before. 'But why?' asks Gratia, 'Why did you burn them? That was our history.' Teresa had made a summary in Spanish, then edited it again to translate it into English. 'Maybe I was wrong', she concedes. As the new superior she had sat lightly enough to convent conventions- her Christmas gift to each sister that first year was a small Swiss Army pocket knife-but the Notebooks had been too full of the hard work and loneliness that traumatised her predecessor: 'Sister Felicitas was always crying, every day picking stones, every night crying'. Judged unedifying, the shadow of the Notebooks survives to show above all what the later generation thought should be preserved.

26 Teresa González in Teresa González, Pilar Catalan, Francisca Pardo and Maria Gratia Balagot, Interview, Madrid, 9 July 2004. 


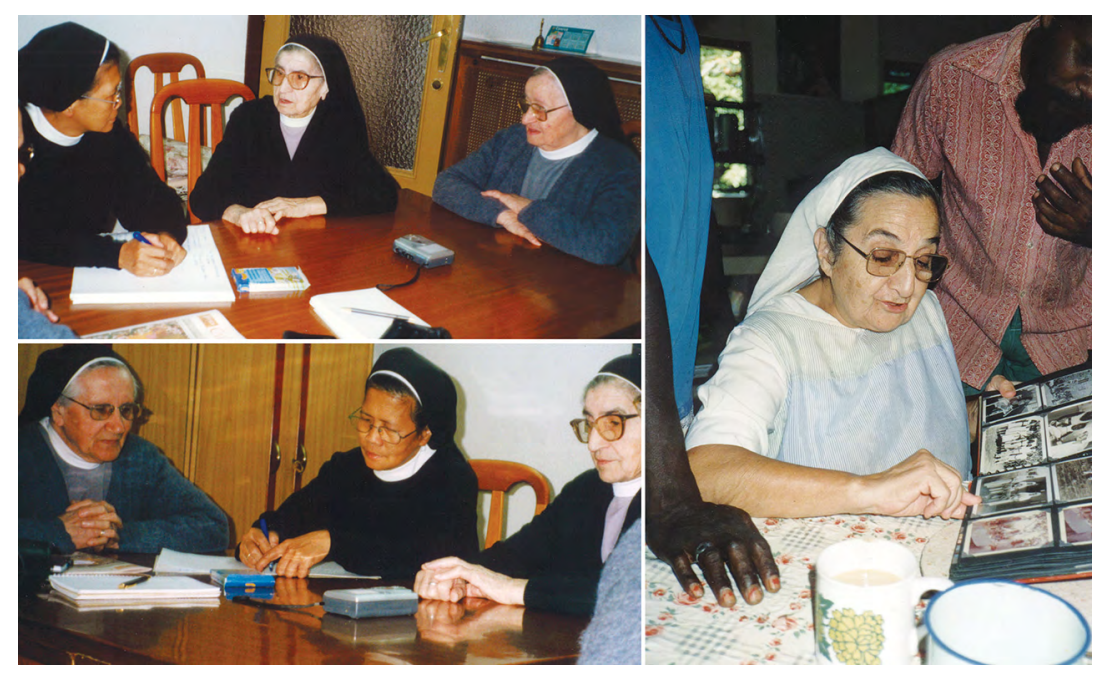

Figure 1.3: Teresa, Francisca, Pilar and Maria Gratia recording memories of the mission around the library table in Madrid, 2004 (left); Scholastica telling the stories of her photo album in Kalumburu, 1999 (right).

Source: Author's collection.

In the same way, some rare letters from the Benedictine women themselves testify to expectations and the quality of relationships as much as they provide details of the life. There is a trail in Spanish and English of official documentation and letters, and it is especially letters written by the third abbot of New Norcia, Anselm Catalan, that provide a narrative spine to the account of the Spanish sisters. Writing to contacts in Spain to promote the mission, explaining the work to prospective recruits, negotiating migration requirements, discussing the sisters with other monks, and corresponding directly with the women themselves, the abbot indexed his carbon copies annually-placing the sisters in their own category, not monks, not officials, not members of the public. In asides and against the grain of the discussion, these letters carry an elusive but invaluable imprint of the Benedictine women's lives. Beneath these scattered documents, there is the rich vein of memory that energises the stories of 70 years and more of the sisters' interaction with the town and its people. These are the memories, of love and also of pain, that the women sought to name in their reunion. 
To honour that reunion and those memories, this is an account of the Benedictine Missionary Sisters of New Norcia. They were a group of 58 women in all, who travelled to Australia between 1904 and 1958 and ranged in age from 13 to 94. Most of the sisters were Spanish, like the monks of New Norcia, from villages in the north near Burgos, and, like the monks, they arrived in Australia as teenagers, with little English and even less understanding of their new country. They came for different reasons: protesting 'do not ask me why! I came because I came', or 'to work for the mission', or because 'I had an intuition I would be a nun, but I did not know the when or the how, and the abbot made it easy'. ${ }^{27}$ For some, their families supported their going, and the church was a recognised opportunity for adventure, travel, livelihood or holiness. For others, leaving Spain was a wrench that never healed completely, a break from potential and actual careers, motherhood and community, family and other support structures; all left behind because God (or the abbot) asked. Pledged to the Benedictine vows of obedience, stability and 'conversion of life', some stayed 'forever' knowing they belonged; others left within weeks, or felt they should have. All of them seemed to wonder at their commitment and the struggle it brought them, and they variously learnt to laugh at the new life, to love it, or to find ways to survive. Over the years, they were joined in Australia by some of the Aboriginal young women from St Joseph's, two in particular in the 1950s who found an expression of their own identity in the religious community. Five others, European Australians from Perth and one New Zealander, were also drawn to the community through circumstances as diverse as the Spanish women before them.

St Joseph's was a hub for work that the town took for granted. Here the sisters provided basic primary education and hands-on training in domestic work. In rosters with the older girls (at times including everyone aged nine or over), they cooked, washed, sewed, and had responsibility for a full range of domestic and farm tasks, from cleaning the abbey church and decorating the altar with flowers and fine linen, to unblocking the town's sewers using coat hangers. They had branch houses in the Kimberley from 1931, in Bindoon from 1948, in Madrid, Samos, Zaragoza, Barcelona, and Madrid again in the 1960s and, from 1973, in Girrawheen, on the northern fringe of Perth, where they ran the first government-funded community childcare centre.

27 Illuminada Perez [Sr Florentina], Interview, Burgos, September 2010; Teresa González, Interview, Madrid, 17 May 1999; Visitación Cidad, Interview, Madrid, 29 July 2010. 
The chapters that follow trace the sisters' years at New Norcia through four distinct phases, reflecting changes in personalities, circumstances and policies of both church and government. The chronology moves broadly from the community's foundation over a decade from 1904 to 1915, through a time when their status within the church was regularised and codified in the 1930s, to a period of regeneration in the later 1940s, and then departure from New Norcia in the mid-1970s. Throughout the changes in each of those phases, the Benedictine women were forever 'between'. They defied simple labels and were often identified simultaneously in contradictory roles. They were women of prayer, drawn together across racial and ethnic boundaries, working within the various hierarchies of church and state. Competing ideals and demands held them in constant, but often muffled, conversation. As missionary women also vowed to a contemplative life of prayer and work, they were negotiating with Catholic tradition along the boundaries of women's holiness and feminine spirituality. As Spanish women, identified racially as 'Mediterranean' and classified officially as 'aliens', they worked with Aboriginal children in English-speaking, White Australia and spoke the language of citizenship in unfamiliar cadences. As working women charged with professional duties in the school and childcare centres, they juggled the need for access to training with community life, limited recognition of their roles and pragmatic insistence that the show must go on. As domestic workers in a rural farming community, they traded their capacity to labour without complaint with the personal cost of broken health and neglected development. Among themselves, the sisters fought changes that would make any of the demands unimportant, even as experience showed that no individual (and perhaps no community) could meet them all.

Definitions of holiness and femininity, citizenship and motherhood, meaningful work and authority overlapped and tangled with each other as speakers in the conversations multiplied. From the government official promoting assimilation, to the woman psychologist tired of being treated 'as if I were a man'; from church instructions on fasting and forms of prayer, to monks who found their laundry shrunken; from the toddler always hiding in the skirts of Reverend Mother, to the homesick runaway returned by police; from the Sister no one visited in hospital, to the one spared dirty work in the kitchen; from the university summer schools on Aboriginal education, to the school concerts featuring Spanish folkdances: these women found their lives framed by complex and competing claims. And those wider dialogues in turn shaped a deeper negotiation: in the 
routines of a tough institution, the sisters and the children in their care held a muted but intense conversation that spoke simultaneously of motherhood and vowed virginity, obedience and decision-making power, forced removal from families, separation, abandonment, childhood and love.

\section{The reunion unfolds}

It is all there in Sheila Humphries's painting Life at St Joseph's. The painting is shown here not as it hangs in the museum but as it was during the central liturgy of the reunion in the parish church, surrounded by other symbols of the life and work of the women of St Joseph's.

Sheila's description of her work begins at the centre of her image and names the core relationships:

If you look at the picture, in the centre you will see the girls [with the] Aboriginal sitting symbol portraying the girls in the different colour uniforms we had throughout the years that we were in here. Around us you will see in black and white the Aboriginal figure again, showing the nuns ... how we were always protected by them, their love surrounded us, everyday life was around us. ${ }^{28}$

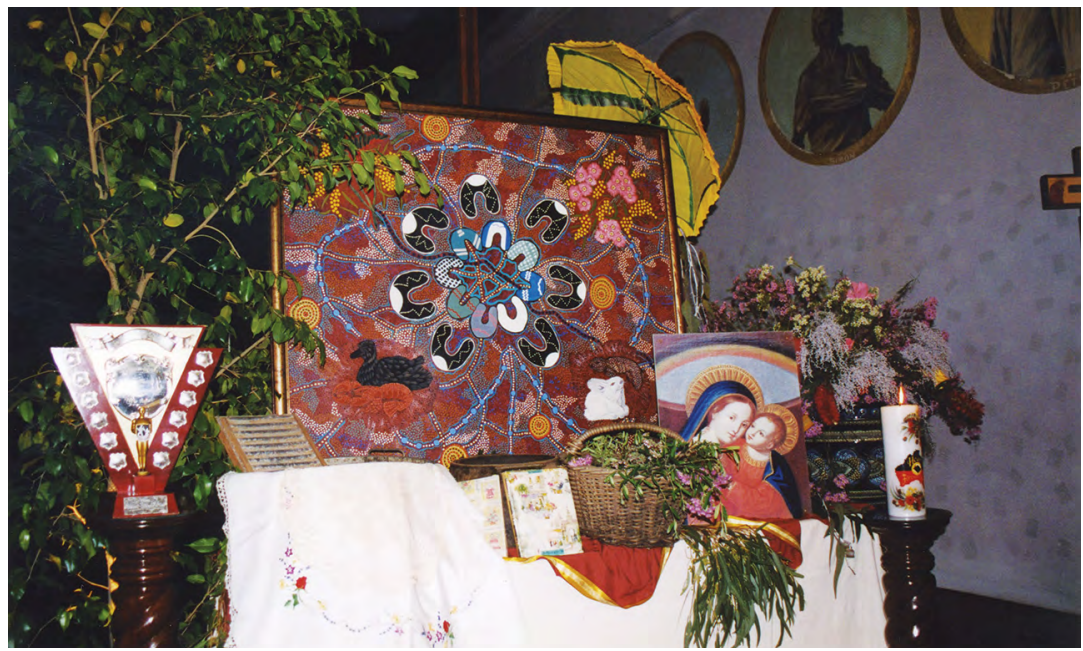

Figure 1.4: Sheila Humphries's painting Life at St Joseph's, within the liturgical display at the reunion, Mass of Thanksgiving, October 2001.

Source: NNA W6-B4-4-208.

28 Humphries, Interview with Sr Anne Carter, 10 June 2002. 
There are two separate circles, one of the children, one of the nuns, and they are coded in separate roles in the colours of institutional dress. But a common symbol represents them both, and one circle encloses the other. Imprisoning? Restricting? No, Sheila says: Protecting. Surrounding. The sisters' love and the details of the everyday surround the girls. Her commentary connects the girls' day-to-day experience directly with the sisters' own situation and the disruption of their ordinary circumstances:

Everyday life was around us, they left their homes, their parents, their families, came out to Australia. Most of them were only teenagers like ourselves, they came out to look after us, knowing very little English. ${ }^{29}$

A strong critic of the monastery in other contexts, Sheila goes on to remark on everyday life in the orphanage:

I'm not denying there were times it was bad, there were times when I wished that Mum and Dad were near, but the Sisters were always there for us. It wasn't just an institution, it was a home where people loved us and looked after us. ${ }^{30}$

The love that the painting records was expressed in simple gestures of companionship. There is another frame in the image beyond the central circles. 'Everyday life was around us', Sheila says. Everyday life involved shared traditions and a shared place:

In the picture you will see different colour dots in the background, representing the earth, grass, and different colours of flowers. The circles on the picture represent the different areas that we went to for walks with the nuns, as you can see the walk sign and the travel sign is all over the picture. ... We travelled all over New Norcia as children with the nuns ... with picnic spots, and areas that we went to swimming, picking wildflowers, chasing rabbits and ducks, and in the rivers catching gilgie for the nuns and the priests. ... When we'd go on picnics we used to chuck'em on the fires and the Sisters used to have a feed with us, so we had our bush tucker. ${ }^{31}$

29 Humphries, Interview, 10 June 2002.

30 Humphries, Interview, 10 June 2002.

31 Humphries, Interview, 10 June 2002. 
The sisters and the girls shared life in a Catholic mission, and life in the Australian country town, essentially on a large farm. They found symbols of a shared Catholic identity in the bush. The painting itself, and Sheila's commentary on it, elides the memory of the bush and the traditions of Catholic belief. The prayer of the rosary, a meditation on the life of Mary the mother of Jesus, who is traditionally dressed in blue, winds through the painting in blue beads that merge with the blue of the local river:

The large blue dots in the painting represent the rosary which was part of our daily life. We said the rosary everyday, and that was very, very dear to us. The river, the dark blue dots that run through the centre of the picture, is the river that runs through New Norcia, the Moore. We spent many, many happy hours in that river, with the nuns, we grew up with the nuns. ${ }^{32}$

Local flowers, identified in the painting with picnic sites and regular walks, also defined sacred spaces for annual processions and adorned the chapel:

The flowers, we used to pick a lot of everlastings when they were in bloom. ... The wattle meant a lot to us because, each year, at Corpus Christi, we used to sprinkle the path where we walked in procession from the church through the two colleges, and then back to the church. The road used to be sprinkled with wattle blossom right through, and we walked over that. Kangaroo paws we used to pick and bring back. A lot of flowers we picked, the Sisters would put them in the church, in our little chapel. ${ }^{33}$

The girls, the sisters, everyday life of traditional devotion and connection with place, and the relationships between them-all accumulated to endorse the institution as a home. Sheila's account stresses above all that it was a home. It was a home in the institutional sense: 'we were in here'. But it was not just an institution, 'it was a home where people loved us and looked after us'. Sheila points to relationships with the other girls, with an absent mum and dad, with the sisters who were near as the first step in explaining St Joseph's.

The relationships, the bonds of shared experience, hold the many stories of St Joseph's and the sisters on a common horizon. They are my point of connection to the story as a researcher and also the barrier that separates me from it. The written records cannot carry the emotional weight of this story. I have relied on the girls, now women, who grew up at St Joseph's,

32 Humphries, Interview, 10 June 2002.

33 Humphries, Interview, 10 June 2002. 
and the young women, now elderly nuns, who travelled up the gravel road to work at the mission. Standing outside both those experiences, my task was daunting. But it was the reunion of 2001 that offered a way forward. As I shared the preparation and the events of the reunion fortnight living alongside the sisters as a general historical rouseabout for the gathering and museum display, I could recite the 'historical facts' as steadily as anyone. I knew from the documents that the institution of St Joseph's itself goes back to 1867, the time of New Norcia's founder. But in 1933 Andrea Pardo, then aged 16, and Pilar Catalan, then aged 15, travelled to New Norcia and became Sister Francisca and Sister Placida. In 1948 Amalia González a 22-year-old teacher, also arrived in Australia from Spain with 11 other young women and became Sister Marie Therese, later Teresa. In 1950 another six sisters joined them, including Visitación Cidad, then 18, and Carmen Ruiz, then 26. It was the women who were children in the 1940s and 1950s when these sisters arrived who lobbied for and financed the reunion, who stood laughing and crying on the steps of the church 50 years later for one more photo, and one more with the grandkids. It was in these years that policies of racial assimilation and disruption of Aboriginal families were at their height in Western Australia. It was in these years that confidence that St Joseph's was doing good and important work was strongest. Yet the 'facts' were full of ambiguities. As the reunion took shape, the ability to question old assumptions, and to challenge and repudiate them, but to remain committed to the relationships that had been forged was a hallmark of the many and varied interactions. I saw ambiguity ignored. It was transcended by the business of the reunion and the work of remembering itself.

At the reunion, St Joseph's was the centre of life again, and the stories took their meaning from that common centre-even the stories that could not yet be uttered or resolved, as much as those that could not be contained. In silent gestures and in the overflow of words, the stories that sustained the relationships reverberated. They were retold one-to-one, or sitting together in the kitchen, in the monastery parlour, and in the car; polished for journalists, committed to private diaries, incorporated into art and poetry, ritualised and relived in liturgies, laughed over, cried for, expressed in a hug or a hand on the shoulder or paused in a careful turning away. Reducing the experience of being 'a St Joseph's girl' or 'a Spanish missionary Sister' to a single narrative was not possible and was not the point. It was the many stories, even the competing and conflicting stories told by the same person, that forged the deepest and most lasting foundation for understanding. 
In fact, it had been in the reaction against a single, simplifying narrative that talk of a reunion with the Benedictine women had gathered momentum. The documentary The Habits of New Norcia went to air with accompanying press late in 2000 and presented the town's Aboriginal institutions as an unmitigated failure. ${ }^{34}$ Reeling from the experience of seeing their childhoods televised as a stereotype of deprivation, the Aboriginal community had split over who had been interviewed, whose story had been used, how the tapes had been edited, and why anyone thought this would bring an apology from the government anyway. No one argued for a sunny vision of simple rural upbringing or triumphal missionary success, but harsher selections that were also too simple did not help either. In planning for the reunion, New Norcia's women made a choice to include other memories of love and home alongside those of hardship and suffering.

The Christian theologian Miroslav Volf has drawn on his own memories of abusive interrogation to explore what it means to remember 'rightly'; the reunion was an affirmation that, in Volf's words, 'we are not just shaped by memories; we ourselves shape the memories that shape us. ${ }^{35}$ Throughout the days of the reunion, identity as a community was being 'stitched together' to form a 'veritable patchwork quilt ... from the growing mountain of discrete multi-coloured memories' ${ }^{36}$ As part of the process, individuals discarded some stories, featured others, and worked yet other strands into the background. Volf argues that making decisions about the pattern of stories that help constitute our identity is part of being human, a process of individual design that 'will depend greatly on how we sew our memories together, and how others-from those closest to us all the way to our culture as a whole — sew them together for us' ${ }^{37}$ Acknowledging as full a reality as possible provides the strongest foundation. Every human quilt of identity must include dark, tattered, coarse and ugly memories, if we are truthful and remember honestly. Those memories, Volf argues, can support hope for reconciliation.

34 The Habits of New Norcia, dir. Frank Rijavec, with Harry Taylor and Carmelo Musca (Eight Mile Plains, Qld: CM Film Productions, 2000).

35 Miroslav Volf, The End of Memory: Remembering Rightly in a Violent World (Grand Rapids, MI: William B. Eerdmans, 2006), 25.

36 Volf, End of Memory, 25.

37 Volf, End of Memory, 25. 
The reunion was a conscious statement about reconciliation. It was also political, as every meeting of Aboriginal Australians and mission authorities is and was political. But it was driven by concerns that placed it outside the lines of argument about the racism of the past. When talk of inviting the sisters 'home' began, it was fuelled by a longing for relationships and by a recognition of the significance of being together in the right place to talk and reconnect. Plans were mulled over in private, and it was only slowly that the possibility of some public acknowledgment of the sisters' visit grew as an idea.

The reunion was about bonds between people, not structures. It brought together people who had publicly and vehemently criticised the sisters and the institutions at New Norcia with others who had literally spent their savings to finance their return. Most often the women and men who gathered could talk in more than one voice, from more than one standpoint, about their childhoods. Again and again, the reunion was about relationships that had persisted through dreadful, and sometimes wonderful, experiences and that had held firm over many years. In a context where so much had been stolen, there were still relationships to be acknowledged and honoured, in order that, as Sheila Humphries said, summarising for the others, 'people will know there was love in this home' ${ }^{38}$ St Joseph's should not have been their home, but that is not the end of the story. The Aboriginal women themselves claim a more complex account of the Benedictine sisters.

The process of acknowledging complexity to see more clearly and get closer to realities is analogous to the naming of St Joseph's itself. In the first place, the buildings on the southern edge of the town are sometimes not named; the standard public accounts can erase the communities of women from Australia's only monastic town. But then, below the horizon of spires and towers that mark out the public history, other accounts multiply. For example, the complex that was called 'St Joseph's Native School and Orphanage' by the government was 'the convent' or sometimes 'the laundry' for the monks, as it was just 'our place' to the sisters who lived there, and 'The Girls' House' for the Aboriginal children who also lived there, in contrast to 'The Boys' House' on the other side of town. Furthermore, when in 1974 the sisters made their sudden decision to leave and return to Spain, the same complex became the 'New Norcia 
Museum and Art Gallery', housing exhibitions about the farm and the founder and the art collection, with no mention of the convent until 2001 when the exhibition in which Sheila's painting hangs was opened in the space that had once been the chapel. All of the names for the complex were accurate; but each name became more accurate alongside the other names. So also the single stories, powerful in themselves, gained another layer of meaning when brought into dialogue and relationship with other strands of stories. And when the competing claims came into conflict in the conversation, then it was the relationships, especially the bonds of shared experience, that demanded attention, made ongoing conversation possible, and encouraged continuing stories.

Storytelling, the incremental and slow process of forging common memories from different histories, is at the heart of reconciliation for an increasing number of commentators. Elizabeth Pike, a Noongar woman from the south of Western Australia, now a writer in residence at the Aboriginal Catholic Ministry in Melbourne, says good relationships across cultures in Australia could hinge on storytelling:

$[\mathrm{O}]$ ne of the most simple and yet one of the strongest means [for bringing Aboriginal and non-Aboriginal Australians together] is the tremendous power of 'story'. Before we can learn to get along, we have to get to know each other, in order to build firm relationships. Because we are such a minority group in the community, it is often very difficult for non-Indigenous people to meet us. It has often been my experience that when contact is made with genuine people, barriers are often broken down quickly. However, when this is not possible, the power of story can awaken the awareness and begin to stir the compassion needed in the depths of one's being. It requires very little intelligence to know that 'love' cannot be bought, sold or legislated in a document and love is what relationships are founded on. ${ }^{39}$

Here Pike is in tune with the international literature that argues for reconciliation as a dimension of spirituality. Approached theologically or understood as a spiritual task, reconciliation emerges most surely from ongoing relationships, from listening to the stories at the deepest level rather than simply from well-managed strategies or well-intentioned therapies. In particular, sharing stories to search for points of connection

39 Elizabeth Pike, 'Reconciliation, or Conciliation through Restoration?', in Developing an Australian Theology, ed. Peter Malone (Strathfield, NSW: St Paul's Publications, 1999), 38-39. 
breaks down barriers. At New Norcia those connections and resonances that keep their shape in more than one narrative might well include the rosary, the Corpus Christi processions, the shared picnics, and the river. Furthermore, it is the stories told 'against the grain' of well-worn narrative tracks that probably contribute most to the healing of reconciliation. ${ }^{40}$ In particular, as Robert Schreiter, a contextual theologian from North America, argues, it is in moments when the initiative lies with the people who have been without power and whose voices have not been heard that the potential for reaching common understanding is greatest. The invitation to us from the past pupils of St Joseph's to hear the sisters' stories and their own stories of the sisters at the reunion is all the more important in this light.

It is not just the telling of stories alone that advances understanding. Simply layering in another account, watching the contradictions, is just confusing without some signposts for the discussion. The international experience is full of examples of groups 'speaking past each other' with the best will in the world. ${ }^{41}$ But it was Herodotus long ago who pointed out that history has always involved interpretation, that the very word 'historeo' means both 'I gather the evidence' and 'I tell my story'. It was the distinguished Australian historian Keith Hancock who reflected on Herodotus as he offered a rubric for understanding the past. Hancock argued that good historical interpretation demanded three things: attachment, justice and span. ${ }^{42}$ This three-part hermeneutic for historical storytellers is still useful. It echoes in the rubric proposed by Rowan Williams where the past is both 'familiar' and 'strange', and in Catherine Chin's quest for the 'radiance' of history, encountered through empathetic and stubborn engagement with 'otherness that can never be entirely domesticated'. ${ }^{43}$ Both the process of research and the stories we tell out of that work depend for their integrity on engaging deeply with the fragments and memories of the past and recasting them onto new canvases that have both breadth and depth. Historians know well that simply hearing alternative voices

40 Robert J. Schreiter, Reconciliation: Mission and Ministry in a Changing Social Order (Maryknoll, NY: Orbis Books, 1992), 45.

41 Charles Villa-Vicencio, 'Telling One Another Stories: Towards a Theology of Reconciliation', in The Reconciliation of Peoples: Challenge to the Churches, ed. Gregory Baum and Harold Wells (Maryknoll, NY: Orbis Books, 1997), 30-42.

42 W. K. Hancock, Professing History (Sydney: Sydney University Press, 1976), 2, 4-7.

43 Rowan Williams, Why Study the Past? The Quest for the Historical Church (London: Darton, Longman and Todd, 2005), 10-11, 88-95; Catherine Chin, 'Marvellous Things Heard: On Finding Historical Radiance', The Massachusetts Review 58 (2017): 478-91. 
is more likely to open questions than to settle them, and sitting with competing interpretations is not the same thing as resolving a narrative line. Increasingly, readers appreciate that meaningful conversation with the past requires a common acknowledgment of divergent experiences and a commitment to search for 'symbols that unite and stories that bind'. ${ }^{44}$ As Inga Clendinnen asks in her work on encounters between Aboriginal Australians and early Europeans: 'Why concoct a single, simple and therefore necessarily false tale and call it Australia's history? Why not a cornucopia of true stories which would tell us what happened?'45 She urges a 'dance' of history that is disciplined by past realities and distinct from fiction and also alert to the power of myth and legend. Against tight certainties of the history warriors she recommends a 'crabwise approach, eyes swivelling sideways, backwards, forwards, with equal intensity, because while the past is the past, it is not dead'. ${ }^{46}$ As historians of Australia have been saying increasingly since the 1990s, deep understanding does not necessarily involve dichotomous choices but might require more inclusive reading of the multivalent evidence of, for example, 'resistance to' and 'co-operation with' and 'flight from' and 'abuse by' and 'interpretation of' colonising powers. ${ }^{47}$ Reconciliation is forged slowly in relationship and conversation.

For Hans-Georg Gadamer, a philosopher concerned with the practical implications of how we understand language, the reconciling conversations depend on a 'fusion of horizons' if they are to arrive at common and enabling memories. ${ }^{48}$ The metaphor is a striking one, especially for New Norcia. For travellers, the town rises distinctively against the horizon of the Victoria Plains, a sudden Spanish apparition, or puzzle, or even disruption, on the Great Northern Highway. Against the horizon it provokes particular questions and requires specific stories. In the town itself, and especially overnight, the sky is vast. The limitless horizon prompts the need for bearings within a cosmic hinterland and recasts the

44 Villa-Vicencio, 'Telling One Another Stories', 32.

45 Inga Clendinnen, True Stories (Sydney: ABC Books, 1999), 101.

46 Clendinnen, True Stories, 103; Stuart Macintyre and Anna Clark, eds, The History Wars (Melbourne: Melbourne University Press, 2004).

47 Lorenzo Veracini, 'Of "Contested Ground" and an "Indelible Stain": A Difficult Reconciliation between Australian and Its Aboriginal History during the 1990s and 2000s', Aboriginal History 27 (2003): 225-39.

48 Hans-Georg Gadamer, Truth and Method, 2nd rev. ed., trans. J. Weinsheimer and D. G. Marshall (New York: Crossroad, 1989); Hans-Georg Gadamer, Hans-Georg Gadamer on Education, Poetry, and History: Applied Hermeneutics, ed. Dieter Misgeld, Graeme Nicholson, Lawrence Schmidt and Monica Reuss (Albany: State University of New York Press, 1992). 
parameters of the town. ${ }^{49}$ Gadamer suggests that the telling and hearing of stories so as to find where the horizons meet is crucial to reconciliation. This involves more than analysis of different perspectives, although the differences are not to be ignored, and more than empathy, although mutual empathy is taken for granted before real storytelling occurs. Reconciliation requires a shift of perception and a mutual recognition of the deepest dimensions of reality that stories can express. When meaning 'happens', to use the verb that theologian Sandra Schneiders applies to interpretation of text, it is because the horizons of the world of the listener and the world of the storyteller have fused, each expanding to forge a new understanding. ${ }^{50} \mathrm{~A}$ fusion of horizons enables people with different stories to recognise the experience behind each other's words and metaphors, to 'crack the code' so as to embrace a more complex (not neater) reality:

[The fusion of horizons] always involves the attainment of a higher universality that overcomes, not only our own particularity, but also that of the other. The concept of the 'horizon' suggests itself because it expresses the wide, superior vision that the person who is seeking to understand must have. To acquire a horizon means that one learns to look beyond what is close at hand-not in order to look away from it, but to see it better within a larger whole and in truer proportion. ${ }^{51}$

This necessarily acknowledges what the American public historian Michael Frisch calls a 'shared authority' between many strands of evidence, and the development of strategies for 'shared authorship' between the public record and other storytellers. In this vision, scholarly work is another tool for community understanding. ${ }^{52}$ It implies, as Robert Orsi, historian of American Catholicism, argues, that fieldwork is 'not a matter of taking notes, but of comparing them, ${ }^{53}$ and that research is an encounter that changes people. Most fundamentally, it recognises that the process by which we discover meaning is one of dialogue. This is remembering and storytelling from what might be called a meditative stance, not just a political, intellectual, or administrative one.

49 See similarly Abbot Placid Spearritt, Friends of New Norcia Newsletter, 23 December 2001.

50 Sandra M. Schneiders, The Revelatory Text: Interpreting the New Testament as Sacred Scripture

(San Francisco: HarperSanFrancisco, 1991).

51 Gadamer, Truth and Method, 272.

52 Michael Frisch, A Shared Authority: Essays on the Craft and Meaning of Oral and Public History (Albany: State University of New York Press, 1990), xix-xx.

53 Robert Orsi, Between Heaven and Earth: The Religious Worlds People Make and the Scholars That Study Them (Princeton, NJ: Princeton University Press, 2005), 174. 
In his book on what it means to remember 'rightly', the work that seems to point towards so many themes of the reunion, Miroslav Volf argues that the infinite horizon of Love and Grace is definitive for people of faith. This is the horizon that enables a meditative, and essentially 'gracious', stance. Volf explores how a God who is Love both challenges and enables people of faith to make memory 'a bridge between adversaries instead of a deep and dark ravine that separates them'. ${ }^{54}$ Far from recommending that conflict should just be ignored or forgotten, Volf holds that memories, including those of injustice and suffering, can become salutary, not destructive; they can be 'redeemed and transformed' without denial or repression. ${ }^{55}$ This is hard spiritual work, but in a secure context, where experiences have been recounted truthfully and moral judgement has been made and accepted, ultimately (and Volf means that literally, at the end time, in God's new creation), memories of suffering will have no power. In the redeemed world of Love and Grace, the memories of wrong will 'not-come-to-mind', as a consequence of God's gift of healed relationships in a redeemed world. In the meantime, in the imperfect world in which the reunion took place, the promise of the infinite horizon means 'every act of reconciliation, incomplete as it mostly is ... stretches itself toward completion in that world of love. ${ }^{56}$

The work of reconciliation at New Norcia is far from complete, but the gathering in 2001 was lived out in the hope of 'a world set aright'. It even offered glimpses of that reality. The reunion at New Norcia did not bring people together as adversaries. It could have done so, easily. Missionary denial and pride could have met Aboriginal accusation and blame, or hierarchical condescension could have met feminine disdain, and the occasion could have become a series of textbook cases of what Volf calls 'contractual' interactions based on the logic of what is supposedly or actually deserved. Instead, the reunion was lived out of a 'logic of grace', marked by 'covenantal' relationships where people assumed they belonged together. ${ }^{57}$ The 'members of the reunion' gave priority to the relationships between them and were generous to each other, as they knew God to be generous on the infinite horizon. They shared relationships forged in the context of the mission town where the girls saw that the sisters were 'teenagers like us', 'always there for us', and where the sisters held

54 Volf, End of Memory, 35.

55 Volf, End of Memory, 144-45.

56 Volf, End of Memory, 150.

57 Volf, End of Memory, 144n36. 
that they had come 'to help the people, to serve', being adamant that 'God does not exploit' (even when, as Abbot Placid observed, 'monks and institutions do'). Those relationships gave an expectation of ongoing connection and the hope of further, ongoing, reconciliation. Memory became not only a 'space of experience' in which the past entered the present but also a 'horizon of expectation' stretching the present forward towards a new way of relating in future. ${ }^{58}$

The gradual breaking open of new meaning in this kind of storytelling seems to me to be akin to the monastic practice of sacred reading, lectio divina, the slow mulling over sacred text taught by the desert monastics in the third and fourth centuries. The steady listening that stretches and transforms reality is an ancient and particularly Benedictine approach to prayer, human healing and growth. It recognises that meaning is an event, an active process for the listener who takes the story to heart. This style of engagement is not about gathering information or seeking 'raw facts' but much more about the potential for change at the level of being. It echoes the teaching of Miriam-Rose Ungunmerr-Baumann that 'deep listening', or dadirri in the language of her Ngangikiurungkurr people from Daly River, is central to healing. The reciprocal process of paying attention, practising 'quiet, still awareness—something like what you call contemplation' - opens new layers of meaning. ${ }^{59}$ The invitation to access 'the larger whole' through stories told and heard is an invitation to encounter the evidence of the past in a dialogue that is potentially transformative. ${ }^{60}$ This style of deep listening as part of research involves being open to living out new relationships.

58 Reinhart Koselleck, Futures Past: On the Semantics of Historical Time, trans. Keith Tribe (Cambridge, MA: MIT Press, 2004), 287-88; Volf, End of Memory, 98-100.

59 Miriam Rose Ungunmerr-Baumann, 'Dadirri: Listening to One Another', in A Spirituality of Catholic Aborigines and the Struggle for Justice, ed. Joan Hendricks and Gerry Heffernan (Brisbane: Aborigines and Torres Strait Islander Apostolate, Catholic Archdiocese of Brisbane, 1993), 34-37. For work that approaches Indigenous trauma using dadirri as the research method, see Judy Atkinson, Trauma Trails, Recreating Song Lines: The Transgenerational Effects of Trauma in Indigenous Australia (North Geelong, Vic.: Spinifex Press, 2002).

60 Gadamer, Truth and Method, 379. 


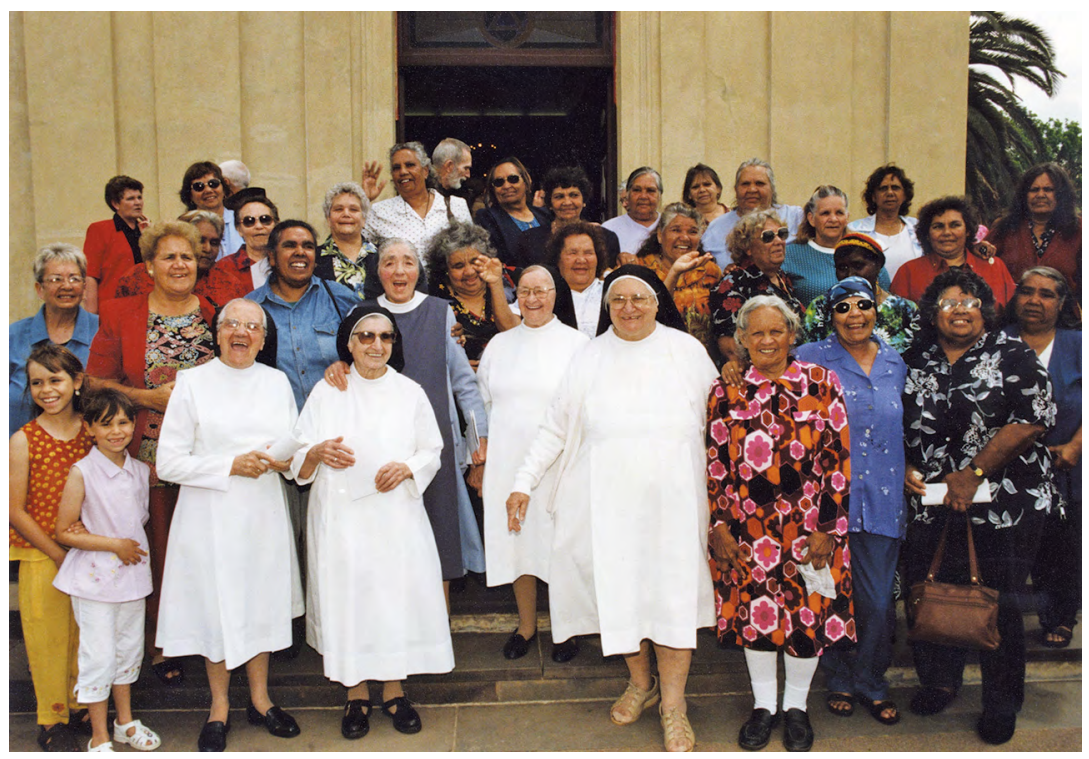

Figure 1.5: Members of the reunion on the steps of the Abbey Church, October 2001.

Source: Newsletter of the Aboriginal Corporation of New Norcia, 2008.

The final public statements of the reunion encapsulated the whole. At the opening of the new museum exhibition on 'Life at St Joseph's', Abbot Placid spoke for the community, thanking contributors and the people gathered at the opening. Sheila Humphries spoke for the former students and introduced the primary school girls, who, dressed in white frocks in the best New Norcia tradition, gave bunches of red roses to each of the sisters. Then together, Sister Francisca and Mae Taylor unveiled the exhibition plaque. At the very end, Sister Teresa spoke again on behalf of the Benedictine women, taking her turn on the stage at the front of the school hall at St Joseph's. The hall had not been there in her time at the school, but it was not unlike the classroom she fronted as a young teacher in the early 1950s, and she addressed a crowd of former students, now with their grandchildren on their knees.

Without notes, without rehearsal, and almost without warning, her words commanded attention at the end of the long day. Remember New Norcia, she said; remember why the sisters came, remember the good that they hoped New Norcia would stand for, remember above all the relationship that stands firm over decades. It was that relationship that made her exhortation both possible and compelling and brought a common 
horizon into view. No one in that room could doubt the validity and depth of the bonds between the sisters and the people. They knew enough of each other's stories to begin to grasp the larger whole. On behalf of the sisters, Teresa's final words were simply of thanks. Flipping the dynamic of acknowledgment, she spoke frankly of the love that fused their realities: 'We came to teach you and you have taught us. You are in our hearts. It is good to know that we are in your hearts'. There were no further words, just applause as proceedings ended and movement as people converged at the edge of the room for photographs. The former students presented a banner to the sisters, with signatures and handprints: to name and to remember. 
This text is taken from A Bridge Between: Spanish Benedictine Missionary Women in Australia, by Katharine Massam, published 2020 by ANU Press, The Australian National University, Canberra, Australia. 